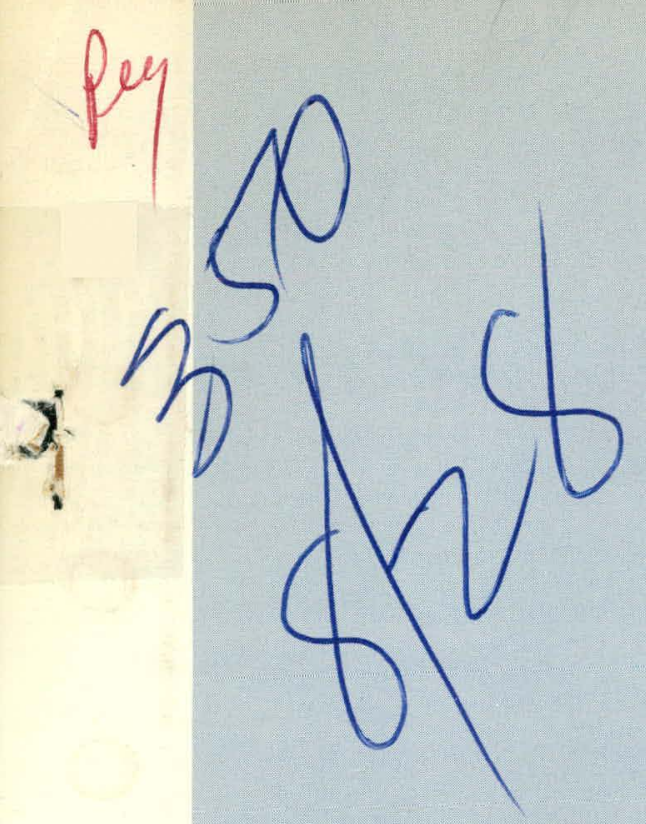

\title{
A STUDY OF POLLUTANT DISCHARGES FROM REACTOR OPERATIONS UTILIZING ULTRACENTRIFUGATION TECHNIQUES
}

AUTHOR:

J. W. Amburgey, Jr.

\section{UNION CARBIDE CORPORATION}

\section{NUCLEAR DIVISION}

Operating the

OAK RIDGE GASEOUS DIFFUSION PLANT • OAK RIDGE NATIONAL LABORATORY OAK RIDGE Y.12 PLANT

- PADUCAH gaseous DIFFusion PLANT 


\section{DISCLAIMER}

This report was prepared as an account of work sponsored by an agency of the United States Government. Neither the United States Government nor any agency Thereof, nor any of their employees, makes any warranty, express or implied, or assumes any legal liability or responsibility for the accuracy, completeness, or usefulness of any information, apparatus, product, or process disclosed, or represents that its use would not infringe privately owned rights. Reference herein to any specific commercial product, process, or service by trade name, trademark, manufacturer, or otherwise does not necessarily constitute or imply its endorsement, recommendation, or favoring by the United States Government or any agency thereof. The views and opinions of authors expressed herein do not necessarily state or reflect those of the United States Government or any agency thereof. 


\section{DISCLAIMER}

Portions of this document may be illegible in electronic image products. Images are produced from the best available original document. 
Printed in the United States of America. Available from Clearinghouse for Federal Scientific and Technical Information, National Bureau of Standards,

U.S. Department of Commerce, Springfield, Virginia 22151

Price: Printed Copy $\$ 3.00$; Microfiche $\$ 0.65$

\section{LEGAL NOTICE}

This report was prepared as an account of Government sponsored work. Neither the United States, nor the Commission, nor any person acting on behalf of the Commission:

A. Makes any warranty or representation, expressed or implied, with respect to the accuracy, completeness, or usefulness of the information contained in this report, or that the use of any information, apparatus, method, or process disclosed in this report may not infringe privately owned rights; or

B. Assumes any liabilities with respect to the use of, or for damages resulting from the use of any information, apparatus, method, or process disclosed in this report.

As used in the above, "person acting on behalf of the Commission" includes any employee or contractor of the Commission, or employee of such contractor, to the extent that such employee or contractor of the Commission, or employee of such contractor prepares, disseminates, or provides access to, any information pursuant to his employment or contract with the Commission, or his employment with such contractor. 


\section{A STUDY OF POLLUTANT DISCHARGES FROM REACTOR OPERATIONS \\ UTILIZING ULTRACENTRIFUGATION TECHNIQUES}

J. W. Amburgey, Jr.

Biophysical Limnology Laboratory

Separation Systems Division

\section{LEGAL NOTICE}

Laccount of Goverament sponsored work. This report was prepared as an accoun of Govera in behalf of the Commiosion: states, nor the Commission, nor any person acting on behall un thed, with respect to the accuA. Makes any warranty or representation, exprescontained in this report, or that the use racy, completeness. or usefuiness of the informallon cosclosed in this report may not infringe of any information, apparatus, method, or process disclosed in this report
privately owned rights; or

B. Assumes any liabilities with respect to the use of, or for damages resuth

use of any information, apparatus, method, ox process disclosed in this report. As used in the above. "person acting on behalf of the Commisslon" includes any employee or contractor of the Commission, or employee of such contoch contractor prepares, such employee or contractor of the Commission, or employee of such contractor prentract disseminates, or provides access to, any information pursuant

with the Commission, or his employment with such contractor.

UNION CARBIDE CORPORATION

NUCLRAR DIVISION

Oak Ridğe, Tennessee 
THIS PAGE

\section{WAS INTENTIONALLY \\ LEFT BLANK}


Report Number: K-1754
Subject Category: WATER POLUUTION

(Distribution: UC-4I and UC-48)

Title: A STUDY OF POLLUTANT. DISCHARGES FROM REACTOR OPERATIONS UTILIZING ULTRACENTRIFUGATION TECHNIQUES

Author: J. W. Amburgey, Jr.

\begin{abstract}
Reactor cooling water samples from the Hanford Operation at Richland, Washington, have undergone particulate separations and study utilizing recently developed ultracentrifugation techniques. The suspended particles contained in these samples were separated into classified groups and then subjected to a variety of analytical investigations including elemental and radiochemical analyses. The samples selected for study were taken in sets ranging from one to four samples per set. Six sets or a total of sixteen samples were collected and shipped to the Biophysical Limnology Laboratory at Oak Ridge for study. The analytical results from these investigations are summarized in a series of tables. The content of selected elements and the radioactivity for the more prominent radionuclides are shown as associated with either the particulate or the dissolved fractions contained in the original sample volume.
\end{abstract}

A few of the radionuclide parent elements such as chromium, sulphur, and zinc were found almost entirely associated with the dissolved materials fraction. These results along with the other data showed that the suspended materials isolated from the various samples of reactor cooling water did not add significantly to the production of radionuclides and the radioactive pollution of the Columbia River at Hanford. 
THIS PAGE

\section{WAS INTENTIONALLY LEFT BLANK}


A STUDY OF POLLUTANT DİSCHARGES FRÖM REACTOR OPERATIONS UTILIZING ULTRACENTRIFUGATION TECHNIQUES

\section{TABLE OF CONTENTS}

INTRODUCTION . . . . . . . . . . . . . . . . 9

SUMMARY AND CONCLUSIONS . . . . . . . . . . . . . . . . . 9

SYSTEMS . . . . . . . . . . . . . . . . . . 11

FRACTIONATING TECHNIQUES :. . . . . . . . . . . . . . . . 11

THEORETICAL CONSIDERATIONS . . . . . . . . . . . . . . 13

EXPERIMENTAL PLAN AND RESULTS . . . . . . . . . . . . 16

REFERENCES . . . . . . . . . . . . . . . . . 17

ACKNOWLEDGMENTS . . . . . . . . . . . . . . . . . . . 17

APPENDIX - ELEMENTAL AND RADIOACTIVITY DISTRIBUTION . . . • . 25 
‘

THIS PAGE

\section{WAS INTENTIONALLY LEFT BLANK}




\section{A STUDY OF POLIUTANT DISCHARGES FROM REACTOR OPERATIONS UTILIZING ULTRACENTRI FUGATION TECHNIQUES}

\section{LIST OF FIGURES AIND TABLES}

Figure 1 - Schematic Diagram of Centrifuge Core and Rotor System

Figure 2 - Relationship Between Sedimentation Coefficients, Rotor Speeds, and Sample Flows

Figure 3 - Schematic Diagram of Vacuum Evaporation System

Table I - Miscellaneous Sample Information

Table II - Elemental Concentration in Starting Sample

Table III - Elemental Concentration in Particulate Fractions

Table IV - Elemental Concentration in Dissolved Fraction

Table V - Elemental Distribution - Percent Associated with Particulate Fraction

Table VI - Radioactivity Associated with Original Sample and Isolated Fractions

Table VII - Radioactivity Distribution - Percent of Total Activity in Original Sample

Table VIII - Elemental Distribution in Reactor 100D Influent Water

Table IX - Elemental Distribution in Reactor 100C Influent Water

Table X - Elemental Distribution in Reactor 100C Effluent Water

Table XI - Radioactivity Distribution in Reactor 100C Effluent Water

Table XII - Elemental Distribution in Columbia River Water

Table XIII - Elemental Distribution in Reactor 100K Influent Water

Table XIV - Elemental Distribution in Reactor 100K Effluent Water

Table XV - Radioactivity Distribution in Reactor 100K Effluent Water

Table XVI - Elemental Distribution in Reactor 100K Influent Water

Table XVII - Elemental Distribution in Reactor 100K Effluent Water

Table XVIII - Radioactivity Distribution in Reactor 100K Effluent Water 
THIS PAGE

WAS INTENTIONALLY

LEFT BLANK 


\section{A STUDY OF POLLUTANT DISCHARGES FROM REACTOR OPERATIONS UTILIZING ULTRACENTRIFUGATION TECHNIQUES}

\section{INTRODUCTION}

In 1965 a proposal was submitted to the Atomic Energy Commission suggesting that the Technical Division of the Oak Ridge Gaseous Diffusion Plant investigate the potential application of ultracentrifugation techniques to separating particulate materials from natural water and for promoting studies relating to water pollution and control. Similar separating techniques already were being successfully applied to biological systems and the study of cellular components. The Atomic Energy Commission accepted the proposal and provided the necessary funding beginning with the second quarter of fiscal year 1966. One of the first investigations plarined under the new program included a study of reactor effluent pollutants discharged into the Columbia River from the Hanford Operations at Richland, Washington.

Representatives from Hanford and Oak Ridge met on two occasions to exchange information and to plan the investigation of reactor cooling water utilizing the latest developments in liquid centrifuge systems and separation techniques. The first meeting was held at Oak Ridge, July 29, 1965. At this meeting, Hanford representatives discussed the production of radionuclides in operating nuclear power reactors and some problems associated with the discharge of such contaminarits in reactor effluent cooling water. A second meeting was held at Richland, Washington, July 12, 1967, to review data previously determined and to plan additional experiments.

The scheme established for studying reactor cooling water was divided into two phases: one, the suspended materials contained in samples of cooling water would be separated centrifugally into various particulate fractions; and two, the isolated fractions would undergo selective analytical studies. The intent of the investigation was to obtain reliable analytical data on the waterborne particulate materials and to use this information to help explain the role of these materials in the radioactive contamination of reactor effluent cooling water. The colloidal fractions were of principal concern since very little information had been obtained on these materials and because of previous difficulties in isolating colloidal t'ractions.

This report presents a summary of all data obtained from the various analytical studies made on both particulate and dissolved fractions centrifugally separated from reactor influent and effluent cooling water samples.

\section{SUMMARY AND CONCLUSIONS}

During the first information meeting Hanford representatives described the merhanism of rcactor effluenl pollution, the problems associated 
with such discharges into a natural body of water, and some treatments under consideration. Their presentations can be summarized as follows:

1. The reactor fuel elements tend to accumulate hydrous oxide films that readily sorb certain elements from the cooling water.

2. The sorbed elements are converted into radionuclides after exposure to the high neutron flux field.

3. The radionuclides are discharged in the reactor cooling water effluent stream, apparently resulting from the eventual sluffing-off of the hydrous oxide film.

4. At least four possible corrective approaches have been considered:

a. Additional pre-treatment of the inlet cooling water in an effort. to reduce the concentration of radionuclide parent elements.

b. Treatment of the fuel element cases to inhibit the formation of the film.

c. Treatment of the oxide film to reduce its tendency to sorb the parent elements.

d. Treatment of the coolant effluent stream to remove the particulate associated radionuclides. Some treatments under consideration included settling basins, filtration, and possibly chemical additives.

The representatives from Hanford were told that the ultracentrifuge could separate and concentrate waterborne suspended materials and thereby permit more reliable analytical studies on individual particulate groups. By using this approach it was thought that a better understanding of the pollution problem could be achieved and hopefully would lead to an economical and practical solution.

A total of sixteen reactor cooling water samples of various sizes were collected and processed between July 1965 and November 1967. The first eight samples, ranging in size from one-half to one liter, were used in scoping-type experiments. The results from these preliminary experiments were extremely helpful in planning full scale fractionations on the larger succeeding samples. The larger sample volumes ranged from eighteen to thirty-eight liters.

The results obtained from the centrifugal fractionations and analytical studies did not reveal appreciable amounts of suspended particulate materials in the cooling water. No significant differences in elemental content were detected between reactor influent and effluent water. Therefore it is concluded that any treatment to be considered probably should involve the hydrous oxide film itself, since it is theorized that the dissolved or very small particulate material is sorbed by the film. Apparently some concentration balance is maintained through continual sorption and resolubilization phenomena taking place within the reactors. 
Centrifugation has proven to be an excellent method for fractionating waterborne particulate materials and for promoting studies associated with various aspects of water pollution. It offers very few advantages in the study of dissolved materials. However, the analytical precision associated with the dissolved materials fraction is often enhanced as a result of the removal of the suspended fractions.

These studies utilizing centrifugal techniques have shown that settling basins and ultrafiltration systems, previously being considered, would not have been particularly effective in curbing radionuclide pollution since the radionuclides of principle concern were not found significantly associated with the particulates separated from the effluent cooling water.

Even though material balances were sometimes inconsistent, the revelation of very low particulate content and other analytical data obtained on the various fractions isolated from both influent and effluent cooling water has generated a better understanding of the contamination problems associated with waterborne particulate materials contained in reactor cooling water.

\section{SYSTEMS}

Centrifuge systems must meet two basic requirements before satisfactory separation of suspended materials from natural water can be achieved; one, the system must have sufficient capacities to concentrate the suspended materials from large sample volumes (normally up to 50 liters), and two, rotor dimensions and speeds must be sufficient to remove the ultrasmall colloidal particles. The rotor system selected and used for the reactor cooling water fractionations met these requirements. The rotor was approximately $25 \mathrm{~cm}$ long, $10 \mathrm{~cm}$ in diameter, and designed for a maximum speed of 40,000 rpm. The centrifugal force generated at this speed was $90,000 \mathrm{x} g$ at maximum radius. A Spinco Model L-4 drive system was used to spin the rotor system. Both aluminum and titanium rotors were used in the cooling water studies. The aluminum rotor was used in processing all samples taken prior to Tuly 31, 1967. The titanium one wao used un all later samples.

An aluminum rotor core designed for biological separations was modified specifically for separating and concentrating particulate materials contained in large sample volumes of natural water. A schematic diagram of the core and rotor system is shown in figure 1.

\section{FRACTIONATING TECHNIQUES}

In the basic separations the suspended particles were removed or concentrated to an approximate volume of $300 \mathrm{ml}$. The particles were separated into various particulate groups based on a difference in sedimentation rates for the sedimenting particles. The rotor speed and sample flow selected for removing each sample fraction were based on theoretical 


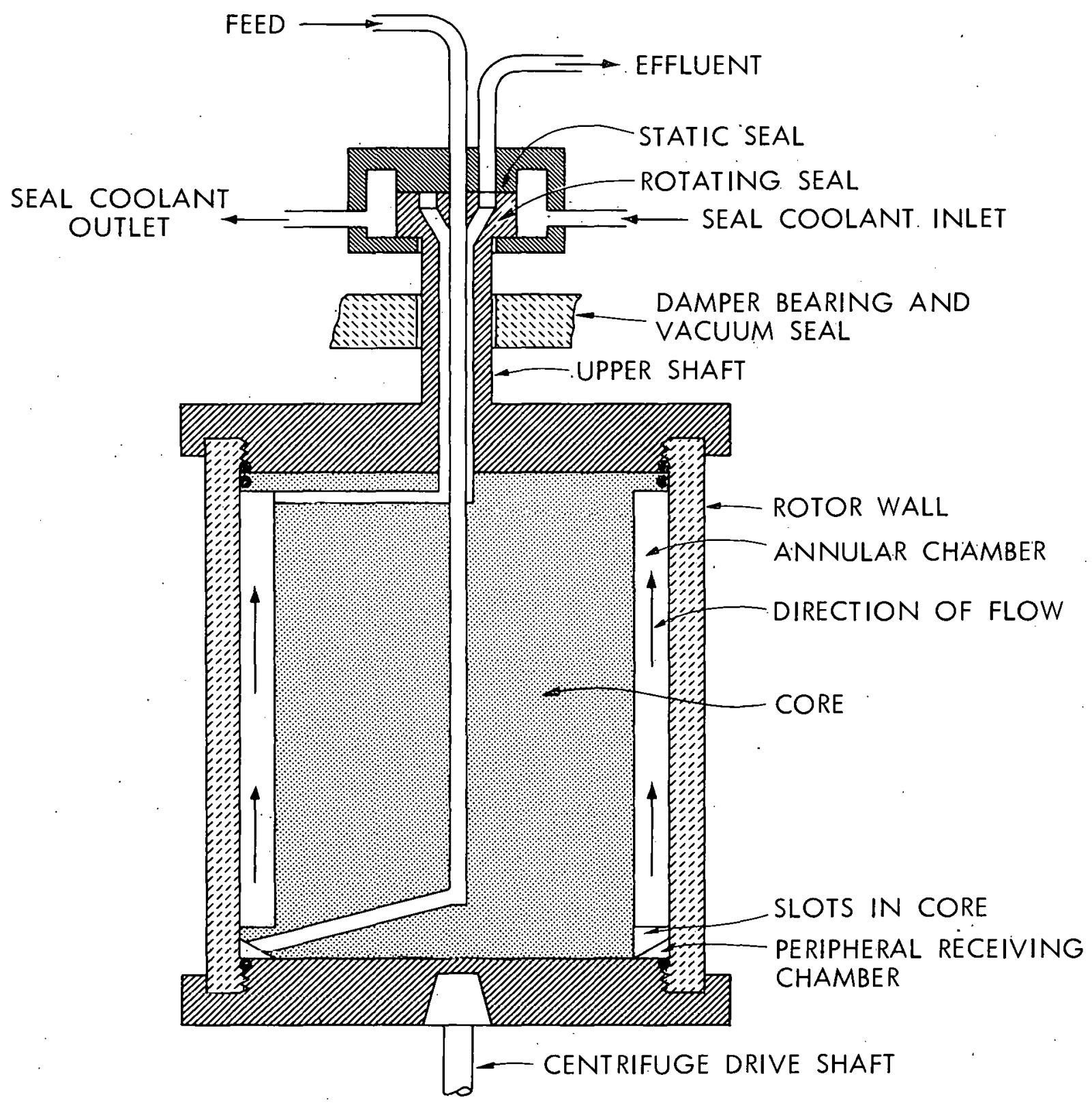

Figure 1

SCHEMATIC DRAWING OF CENTRIFUGE CORE, ROTOR SYSTEM 
calculations shown in figure 2 (1) and depended on the particle sizes desired. During each centrifugation cycle, the sample passing through the spinning rotor was divided into two particulate fractions with the larger particles being retained in the centrifuge rotor and the smaller particles being carried out in the effluent stream. In this way the larger particles were concentrated from the original volume to approximately $300 \mathrm{ml}$. Further concentrations, using other centrifuge, systems, were made in some of the tests.

The final effluent volumes containing some ultrasmall particles (estimated to be less than $150 \AA$ in diameter for particles with a density of $2 \mathrm{~g} \mathrm{~cm}^{-3}$ ) along with the dissolved materials were concentrated to approximately $300 \mathrm{ml}$ by vacuum evaporation techniques and subjected to the same analytical studies as were the particulate fractions. A schematic of the vacuum evaporation equipment is shown in figure 3.

\section{THEORETICAL CONSIDERATIONS}

Figure 2 shows a plot of particle sedimentation coefficient as a function of rotor speed and sample flow. Sedimentation coefficients were approximated from the following equation ( 1 ):

$$
s=\frac{d^{2}\left(\rho_{p}-\rho_{s}\right)}{18 \eta}\left(10^{13}\right)
$$

where

$$
\begin{aligned}
& s=\text { sedimentation coefficient in Svedberg units, } \\
& d=\text { diameter of the sedimenting particle in } \mathrm{cm} \text {, } \\
& \rho_{p}=\text { density of the sedimenting particle in } \mathrm{g} \mathrm{cm}^{-3}, \\
& \rho_{s}=\text { density of the supporting solution in } \mathrm{g} \mathrm{cm} \mathrm{cm}^{-3} \text {, and } \\
& \eta=\text { viscosity of the supporting solution in poise. }
\end{aligned}
$$

A flow rate was selected that would yield a particle fractionation based on its estimated sedimentation coefficient. The sample flow rate requirements were estimated from the following equation ( 1 ):

$$
Q=\frac{\omega^{2} V s}{\ln R_{2} / R_{1}}(3.6)\left(10^{-13}\right)
$$

where

$\mathrm{Q}$ is the sample flow in liters per hour,

$\omega$ is the angular velocity in radians per second, 


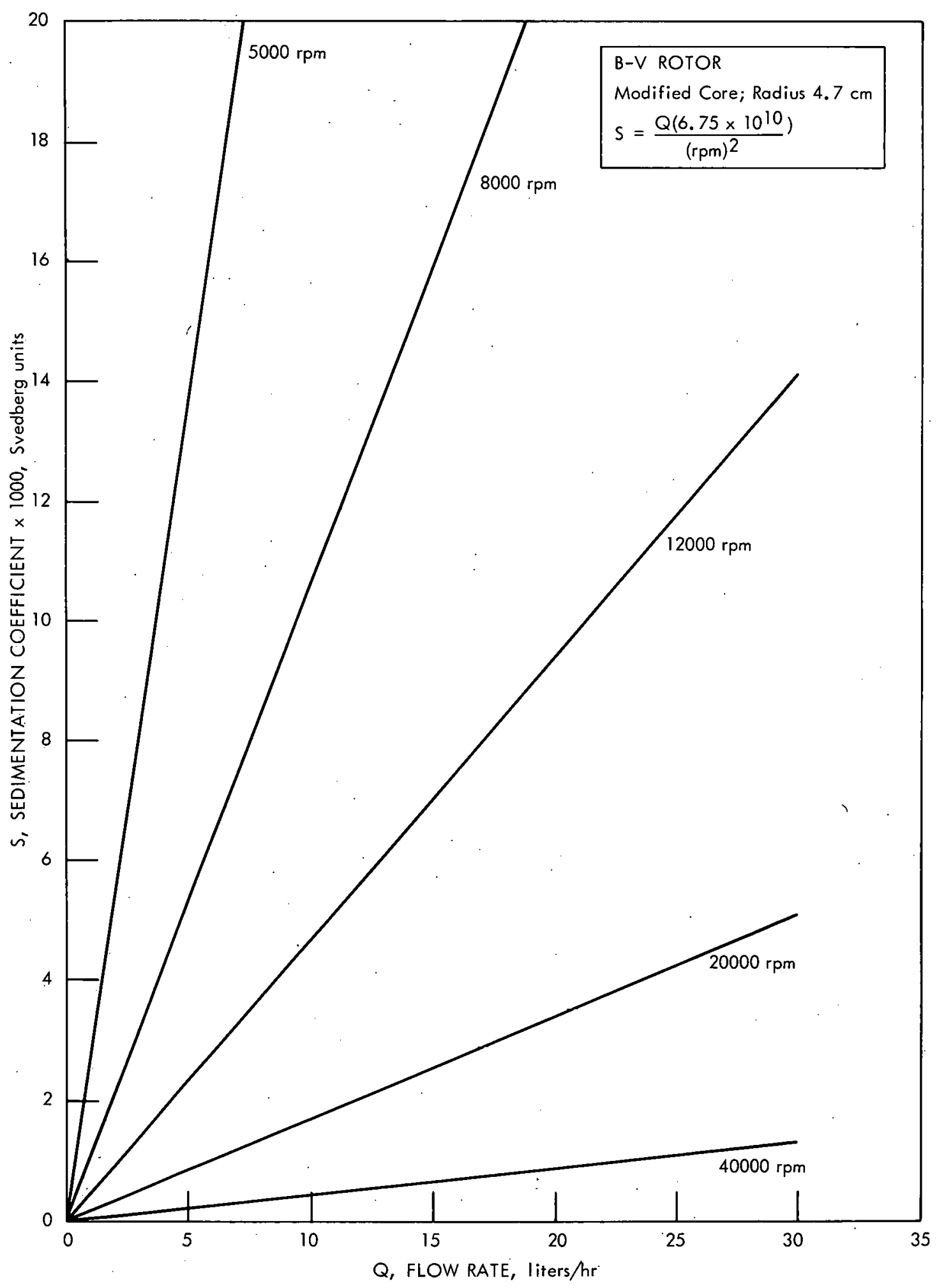

Figure 2

RELATIONSHIP BETWEEN SEDIMENTATION COEFFICIENT AND FLOW RATE AT SEVERAL ROTOR SPEEDS 


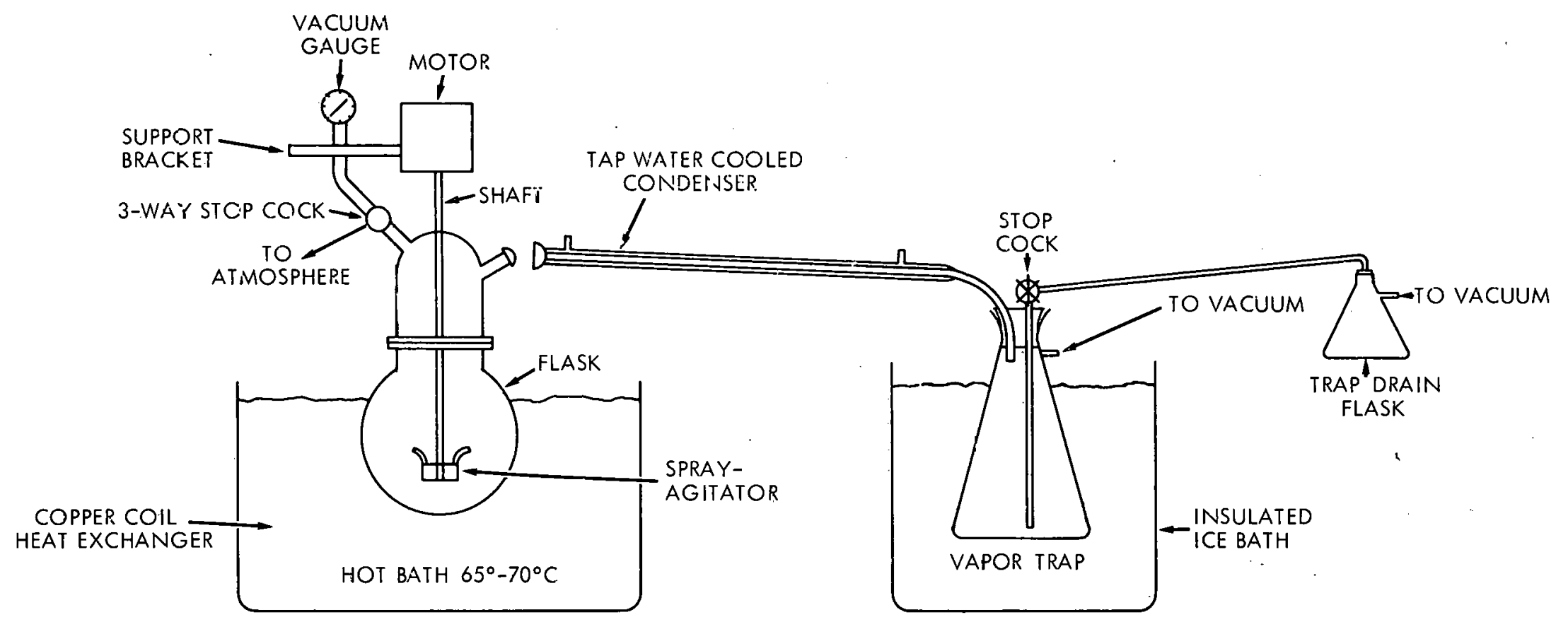

Figure 3

SCHEMATIC OF VACUUM EVAPORATION SYSTEM 
$\mathrm{V}$ is the sample volume exchanged in liters,

$s$ is the sedimentation coefficient in Svedberg units,

$R_{\boldsymbol{z}}$ is the maximum radius in centimeters, and

$R_{1}$ is the minimum radius in centimeters.

EXPERIMENTAL PLAN AND RESULTS

Following the first information meeting, Mr. Robert Geier* and associates left four, one-pint samples of reactor cooling water for our use in some preliminary investigations. The samples represented both influent and effluent water from three different reactor areas. Another set of four, one-liter samples, was received on september 24, 1965. These first eight samples were used in scoping-type experiments. The results from these experiments were used in planning full-scale fractionations on the larger succeeding samples. The following general experimental plan was formulated:

1. Collect minimum sample volumes of nineteen liters.

2. Refrigerate samples (normally less than $5^{\circ} \mathrm{C}$ ) immediately following collection and during transit to suppress biological and chemical activity.

3. Separate and divide the suspended materials into a series of fractions based on a difference in sedimentation rates.

4. Vacuum evaporate the final centrifugal effluent volume and analyze the resulting concentrated dissolved materials fraction.

5. Perform spectrochemical and atomic absorption analyses on each sample fraction.

6. Attempt to identify the larger materials by X-ray diffraction and electron probe techniques.

7. Examine the smaller materials using electron microscopy techniques.

8. Perform radiochemical analyses on all fractions derived from reactor effluent samples.

The analytical data obtained from the larger samples can best be summarized and correlated by combining the results from the different isolated fractions and expressing them all in the same units; preferably in micrograms and picocuries per milliliter in the original sample volume.

* Formerly with General Electric Corporation, currently with Douglas United Nuclear, Inc. 
Table I shows miscellaneous data and information for each of the samples fractionated. Tables II, III, and IV show elemental analysis results for the original samples, the particulate fractions, and the dissolved fractions, respectively. Table $\mathrm{V}$ shows the percent elemental content associated with the particulate material and based on the total amount found in the two fractions. The elemental data on the original sample aliquots are only used for reference since the precision is often much less than that for the two concentrated fractions.

Table VI shows the radioactivity results associated with the particulate, dissolved, and original sample volumes from the reactor effluent streams. In table VII the results are shown as percent of original count and the amount unaccounted for based on a balance between the two concentrated fractions and the original sample. Some of the losses can be accounted for in that analyses on the original containers for samples HK- 6 and -8 indicated that some losses occur as a result of sorbtion effects between the sample and container walls.

In looking at table $\mathrm{V}$ we find only iron and phosphorus consistently high in the particulate fractions. Aluminum results are somewhat inconsistent. This may be accounted for in that some of the centrifuge components are made of aluminum and are probable sources of contamination.

Radiochemical analyses (tables VI and VII) revealed that only phosphorus 32 and scandium 46 were significantly associated with the particulate materials. The other radionuclides; chromium 51, antimony 124, strontium 89-90, and zinc 65 were almost wholly associated with the dissolved materials.

The basic elemental and radioactivity data for each coolant sample studied are shown in the appendix. These data and other pertinent information were sent to R. G. Geier following the fractionation and analytical study made on each set of samples. He and his associates have made their own study and interpretations.

\section{REFERENCE}

1. Svedberg, T. and Pederson, K. O., The Ultracentrifuge, Oxford, The Clarendon Press, 1940.

\section{ACKNOWLEDGMENTS}

The author wishen to acknowledge the assistance of Dr. W. T. Lammers in planning the investigations and making particle counto on the original samples, and the help of the Chemical Development and Chemical Analysis Departments in making special analyses on the various sample fractions. 
TABLE I

MISCELLANEOUS SAMPLE INFORMATION

\begin{tabular}{|c|c|c|c|c|c|c|c|c|c|c|}
\hline \multirow[b]{2}{*}{ No. } & \multirow[b]{2}{*}{ Sample Source } & \multirow{2}{*}{ Taken } & \multirow[b]{2}{*}{ Received } & \multirow[b]{2}{*}{$\mathrm{pH}$} & \multirow{2}{*}{$\begin{array}{l}\text { Conductivity } \\
\text { Micromhos }\end{array}$} & \multicolumn{3}{|c|}{ Particle Count per ml } & \multirow{2}{*}{$\begin{array}{l}\text { Sample } \\
\text { Volume, } \\
\text {.ml } \\
\end{array}$} & \multirow{2}{*}{$\begin{array}{l}\text { Total } \\
\text { Solids, } \\
\mathrm{mg} / \mathrm{ml}^{*}\end{array}$} \\
\hline & & & & & & Bacteria & Organic & Inorganic & & \\
\hline $\mathrm{H}-1$ & 100D Reactor Influent & $1 / 16 / 67$ & $1 / 18 / 67$ & -- & 758 & $2 \times 10^{6}$ & $1 \times 10^{7}$ & $9 \times 10^{7}$ & 19,000 & -- \\
\hline $\mathrm{H}-2$ & 100C Reactor Influent & $3 / 18 / 67$ & $3 / 20 / 67$ & 7.4 & 140 & -- & -- & -- & 19,000 & 0.13 \\
\hline $\mathrm{H}-3$ & 100C Reactor Effluent & $3 / 18,67$ & $3 / 20 / 67$ & 6.7 & 150 & -- & -- & - & 19,000 & 0.13 \\
\hline $\mathrm{H}-4$ & Columbia River & $8 / 28 / 67$ & $8 / 30 / 67$ & 6.7 & 116 & $3 \times 10^{4}$ & $1.5 \times 10^{7}$ & $1.7 \times 10^{8}$ & 19,200 & 0.12 \\
\hline $\mathrm{H}-5$ & 100K Reactor Influent & $8 / 28 / 67$ & $8 / 30 / 67$ & 6.1 & 110 & $<1$ & $1.5 \times 10^{7}$ & $9 \times 10^{6}$ & 19,300 & 0.12 \\
\hline$H-6$ & 100K Reactor Effluent & $8 / 28 / 67$ & $8 / 30 / 67$ & 5.7 & 164 & $<1$ & $2.5 \times 10^{6}$ & $1.7 \times 10^{8}$ & 19,000 & 0.09 \\
\hline $\mathrm{H}-7$ & $100 K$ Reactor Influent & & & & & & & & & \\
\hline & Number 1 & $11 / 12 / 67$ & $11 / 14 / 67$ & 6.4 & 144 & 10 & $3 \times 10^{7}$ & $9 \times 10^{7}$ & 19,200 & 0.14 \\
\hline & Number 2 & $11 / 12 / 67$ & $11 / 14 / 67$ & 6.6 & 128 & $3 \times 10^{7}$ & $4 \times 10^{7}$ & $8 \times 10^{7}$ & 19,200 & 0.14 \\
\hline $\mathrm{H}-8$ & 100K Reactor Effluent & & & & & & & & & \\
\hline & Number 1 & $11 / 12 / 67$ & $11 / 14 / 67$ & 5.4 & 133 & -- & None & $1.6 \times 10^{8}$ & 17,000 & 0.10 \\
\hline & Number 2 & $11 / 12,67$ & $11 / 14 / 67$ & 5.6 & 129 & -- & $9 \times 10^{8}$ & $2.6 \times 10^{8}$ & $i 8,000$ & 0.10 \\
\hline
\end{tabular}

* Solids determined by evaporating sample aliquot to dryness at $100^{\circ} \mathrm{C}$. 
TABLE II

ELEMENTAL CONCENTRATION IN STARTING SAMPLE, $\mu \mathrm{g} / \mathrm{m} 工$

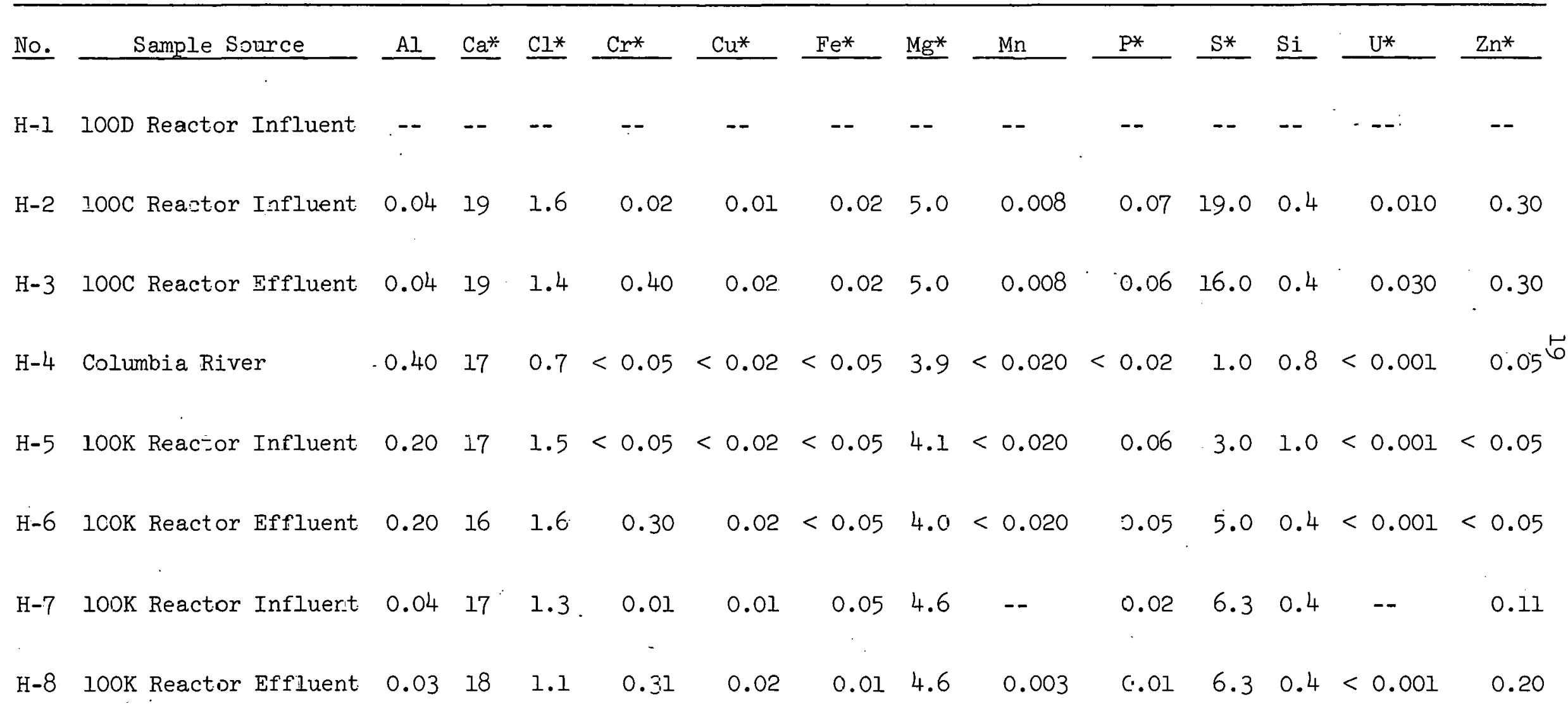

* Normal precision $\pm 20 \%$ of the reported values; all others $1 / 3$ to 3 times this value. 


\section{TABLE III}

ELEMENTAL CONCENTRATION IN PARTICULATE FRACTION, $\mu \mathrm{g} / \mathrm{ml}$

\begin{tabular}{|c|c|c|c|c|c|c|c|c|c|c|c|c|c|c|}
\hline No. & Sample Source & $\mathrm{Al}$ & $\underline{\mathrm{Ca}^{*}}$ & $\mathrm{Cl} *$ & $\mathrm{Cr}{ }^{*}$ & $\mathrm{Cu}^{*}$ & $\mathrm{Fe}^{*}$ & $\mathrm{Mg}^{*}$ & $\mathrm{Mn}$ & $P^{*}$ & $S^{*}$ & $\mathrm{Si}$ & $\mathrm{U}^{*}$ & $Z n^{*}$ \\
\hline $\mathrm{H}-\mathrm{I}$ & 100D Reactor Influent & 0.05 & 0.31 & -- & 0.002 & 0.002 & 0.080 & 0.110 & 0.001 & 0.019 & 0.390 & 0.036 & -- & 0.010 \\
\hline $\mathrm{H}-2$ & 100C Reactor Influent & 0.16 & 0.02 & -- & 0.004 & 0.045 & 0.110 & 0.009 & -- & 1.700 & 0.350 & 0.021 & 0.001 & 0.063 \\
\hline$H-3$ & 100C Reactor Effluent & 0.58 & 0.02 & -- & 0.008 & 0.344 & 0.398 & 0.014 & 0.003 & 0.638 & 0.696 & 0.006 & 0.002 & 0.033 \\
\hline $\mathrm{H}-4$ & Columbia River & 0.09 & 0.03 & 0.010 & 0.001 & 0.003 & 0.042 & 0.017 & 0.004 & 0.003 & -- & 0.296 & -- & $0.003 \mathrm{~N}$ \\
\hline $\mathrm{H}-5$ & 100K Reactor Influent & 0.03. & 0.08 & -- & -- & 0.003 & 0.030 & 0.019 & -- & 0.006 & 0.011 & 0.051 & 0.001 & 0.007 \\
\hline$H-6$ & 100K Reactor Effluent & 0.05 & 0.06 & 0.004 & 0.001 & 0.016 & 0.013 & 0.015 & -- & 0.004 & -- & 0.020 & 0.001 & 0.004 \\
\hline $\mathrm{H}-7$ & 100K Reactor Influent & 0.01 & 0.14 & 0.022 & -- & 0.001 & 0.073 & 0.037 & -- & 0.003 & 0.056 & 0.017 & 0.000 & 0.003 \\
\hline $\mathrm{H}-8$ & 100K Reactor Effluent & 0.01 & 0.17 & 0.020 & 0.003 & 0.002 & 0.004 & 0.045 & -- & 0.006 & 0.070 & 0.010 & 0.006 & 0.003 \\
\hline
\end{tabular}


TABLE IV

ELEMENTAL CONCENTRATION IN DISSOLVED FRACTIOIN, $\mu \mathrm{g} / \mathrm{ml}$

\begin{tabular}{|c|c|c|c|c|c|c|c|c|c|c|c|c|c|c|}
\hline No. & Semple Source & $\mathrm{Al}$ & $\underline{\mathrm{Ca}} \mathrm{C}^{*}$ & $\mathrm{Cl} *$ & $\mathrm{Cr}^{*}$ & $\mathrm{Cu}^{*}$ & $\mathrm{Fe}^{*}$ & $\mathrm{Mg}^{*}$ & $\mathrm{Mn}$ & $\mathrm{P}^{*}$ & $S^{*}$ & $\mathrm{Si}$ & $\mathrm{U}^{*}$ & $\mathrm{Zn*}$ \\
\hline $\mathrm{H}-\mathrm{I}$ & 100-D Reactar Influent & 0.21 & 10.4 & -- & 0.005 & 0.021 & 0.58 & 2.87 & 0.029 & 0.074 & 6.50 & 0.79 & -- & 0.204 \\
\hline $\mathrm{H}-2$ & 100-C Reactor Influent & 1.14 & 11.8 & 1.60 & 0.011 & 2.060 & 0.44 & 3.08 & 0.042 & 6.550 & 11.15 & 1.12 & 0.006 & 0.460 \\
\hline $\mathrm{H}-3$ & 100-C Feactor Effluent & 0.13 & 13.7 . & 1.80 & 0.250 & 0.350 & 0.22 & 3.37 & 0.066 & 2.340 & 11.37 & 1.18 & 0.001 & 0.360 \\
\hline $\mathrm{H}-4$ & Columbia River & 0.07 & 13.4 & $7 \cdot 90$ & 0.003 & 0.007 & 0.027 & 3.14 & 0.004 & 0.020 & 2.05 & 0.82 & -- & 0.026 \\
\hline $\mathrm{H}-5$ & 100-K Reactor Influent & 1.38 & 13.9 & 1.42 & 0.038 & 0.021 & 0.139 & 3.46 & 0.016 & 0.060 & $7 \cdot 94$ & 1.38 & - & 0.200 \\
\hline $\mathrm{H}-6$ & 100-K Reactor Effluent & 0.13 & $\varepsilon .9$ & 1.36 & 0.287 & 0.006 & 0.008 & 3.62 & 0.005 & 0.011 & 5.26 & 0.80 & 0.005 & 0.065 \\
\hline $\mathrm{H}-7$ & 100-K Reactor Influent & 0.10 & 14.3 & 3.00 & 0.009 & 0.008 & 0.013 & 3.91 & 0.001 & 0.008 & 7.94 & 1.25 & 0.000 & 0.090 \\
\hline $\mathrm{H}-8$ & 1CO-K Reactor Effluent & 0.09 & 14.6 & 0.92 & 0.317 & 0.020 & 0.008 & 3.50 & 0.004 & 0.014 & 7.77 & 1.15 & 0.000 & 0.058 \\
\hline
\end{tabular}




\section{TABLE V}

ELEMENTAL DISTRIBUTION - PERCENT ASSOCIATED WITH PARTICULATE FRACTION

[Particulate (100)/Particulate + Dissolved]

\begin{tabular}{|c|c|c|c|c|c|c|c|c|c|c|c|c|c|c|}
\hline No. & Sample Source & Al & $\mathrm{Ca}$ & $\mathrm{Cl}$ & $\mathrm{Cr}$ & $\underline{\mathrm{Cu}}$ & $\underline{\mathrm{Fe}}$ & $\underline{\mathrm{Mg}}$ & $\underline{\mathrm{Mn}}$ & $\underline{P}$ & $\mathrm{~S}$ & $\mathrm{Si}$ & $\mathrm{U}$ & $\mathrm{Zn}$ \\
\hline $\mathrm{H}-\mathrm{I}$ & 100-D Reactor Influent & 19 & 2.9 & -- & 28.6 & 9 & 12 & 3.7 & 3 & 20 & 6.0 & 4.4 & -- & 4.7 \\
\hline $\mathrm{H}-2$ & 100-C Reactor Influent & 12 & 0.2 & 0.00 & 26.7 & 2 & 20 & 0.3 & 0 & 21 & 3.0 & 2.0 & 14 & 12.0 \\
\hline $\mathrm{H}-3$ & 100-C Reactor Effluent & 82 & 0.1 & 0.00 & 3.2 & 49 & 64 & 0.4 & 4 & 21 & 5.8 & 0.5 & 67 & 8.4 \\
\hline $\mathrm{H}-4$ & Columbia River & 56 & 0.2 & 1.36 & 25.0 & 30 & 61 & 0.5 & 50 & 13 & 0.0 & $26: 5$ & -- & 10.0 \\
\hline $\mathrm{H}-5$ & 100-K Reactor Influent & 2 & 0.6 & 0.00 & 0.0 & 13 & 18 & 0.5 & 0 & 9 & 0.1 & 3.6 & 100 & 3.2 \\
\hline$H-6$ & I:00-K Reactor Effluent & 28 & 0.7 & 0.29 & 0.3 & 73 & 62 & 0.4 & 0 & 27 & 0.0 & 20.0 & 17 & 5.8 \\
\hline $\mathrm{H}-7$ & 100-K Reactor Influent & 9 & 1.0 & 0.73 & 0.0 & 1.1 & 85 & 0.9 & 0 & 27 & 0.7 & 1.3 & -- & 3.2 \\
\hline $\mathrm{H}-8$ & 100-K Reactor Effluent & 10 & 1.2 & 2.10 & 0.1 & 9 & 33 & 1.3 & 0 & 30 & 0.9 & 0.9 & 100 & 4.9 \\
\hline
\end{tabular}


TABLE VI

RADIOACTIVITY ASSOCIATED WITH ORIGINAL SAMPLE AND ISOLATED FRACTIONS PICOCURIES / m I**

\begin{tabular}{|c|c|c|c|c|c|c|c|c|}
\hline No. & Source & & $\mathrm{Cr}^{51}$ & $\mathrm{P}^{32 *}$ & $\mathrm{Sb}^{124}$ & $\mathrm{Sc}^{4 \hat{3}}$ & $\mathrm{Sr}^{*}$ & $\mathrm{Zn}^{65}$ \\
\hline \multicolumn{9}{|c|}{ ORIGINAL SAMPLE } \\
\hline HK-6 & 100K Efflue:nt & 193 & \pm 14 & $6.50 \div 0.70$ & $2.82 \pm 2.11$ & $3.60 \pm 1.10$ & $0.43 \pm 0.06$ & $4.80 \pm 1.40$ \\
\hline HK-8 & 100K Effluent & 240 & \pm 15 & $7.40 \pm 0.80$ & $3.31 \pm 2.13$ & $4.20 \pm 1.14$ & $0.04 \pm 0.06$ & $5.10 \pm 1.40$ \\
\hline
\end{tabular}

\section{PARTICULATE FRACTION}

\begin{tabular}{|c|c|c|c|c|c|c|c|c|}
\hline $\mathrm{HK}-6$ & 100K Effluent & $2.88 \pm$ & 0.04 & $0.90 \pm 0.05$ & -- & $0.32 \pm 0.01$ & - & $0.07 \pm 0.01$ \\
\hline $\mathrm{K}-8$ & OOK Effluent & $.30 \pm$ & 0.26 & $2.15 \pm 0.11$ & $0.05 \pm 0.02$ & $0.52 \pm 0.02$ & 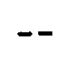 & $0.06 \pm 0.01$ \\
\hline
\end{tabular}

\section{DISSOLVED FRACTION}

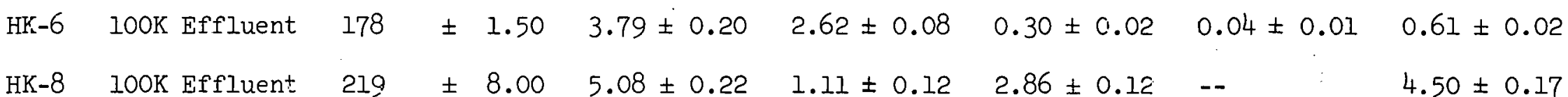

* Beta activitjr; all others gamma activity.

* Results corrected to date of sampling. 
TABLE VII

RADIOACTIVITY DISTRIBUTION

(Percent of Total Activity in Original Sample.)

Sample Number and Source $\quad \underline{\mathrm{Cr}^{51}} \quad \underline{\mathrm{P}^{32 *}} \quad \underline{\mathrm{Sb}^{124}} \quad \underline{\mathrm{Sc}^{46}} \quad \underline{\mathrm{Sr}^{*}} \underline{\mathrm{Zn}^{65}}$

PARTICULATE FRACTION

$\begin{array}{llllllll}\text { HK-3 } & \text { 10OC Reactor Effluent } & 2.1 & 14.7 & - & 8.0 & 0.4 & 6.0\end{array}$

HK-6 100K Reactor Effluent : $1.5: 13.8 \quad--\quad 8.9 \quad--\quad 1.5$

$\begin{array}{lllllllll}\text { HK-8 10OK Reactor Effluent } & 1.4 & 29.1 & 1.5 & 12.4 & -- & 1.2\end{array}$

\section{DISSOLVED FRACTION}

HK-3 IOOC Reactor Effluent 64.5 9.7 $\quad \begin{array}{lllll}23.8 & 78.8 & 77.5\end{array}$

HK-6 100K Reactor Effluent $92.2 \quad 58.3 \quad--8_{3} \quad 8.3 \quad--\quad .12 .7$

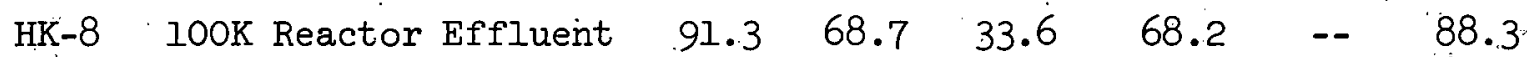

UNACCOUNTED FOR

HK-3 . IOOC Reactor Effluent 33.4. $75.6 \quad--\quad 68.2 \quad 20.8 \quad 16.5$

HK-6 100K Reactor Effluent $6.3 .27 .9 .--\quad 82.8 \quad:--\quad 85.8$

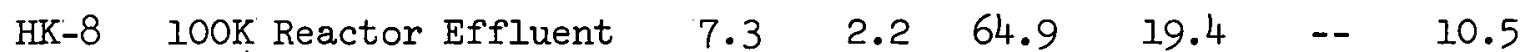

* Beta activity; all others gamma activity. 
APPENDIX

ELEMENTAL AND RADIOACITVITY DISTRIBUTION DATA

Selected elemental determinations were made on each of the original sample volumes, the different isolated particulate fractions, and the final dissolved materials fraction. In addition, radiochemical analyses were performed on each of the fractions derived from samples of reactor effluent cooling water. These analytical results are shown in tables VIII through XVIII as either total elemental weight or radioactivity where applicable for the different coolant samples and isolated fractions. 
TABLE VIII

ELEMENTAL DISTRIBUTION IN REACTOR IOOD INFLUENT WATER (H-I)

(Total Weight in $\mu \mathrm{g}$ )

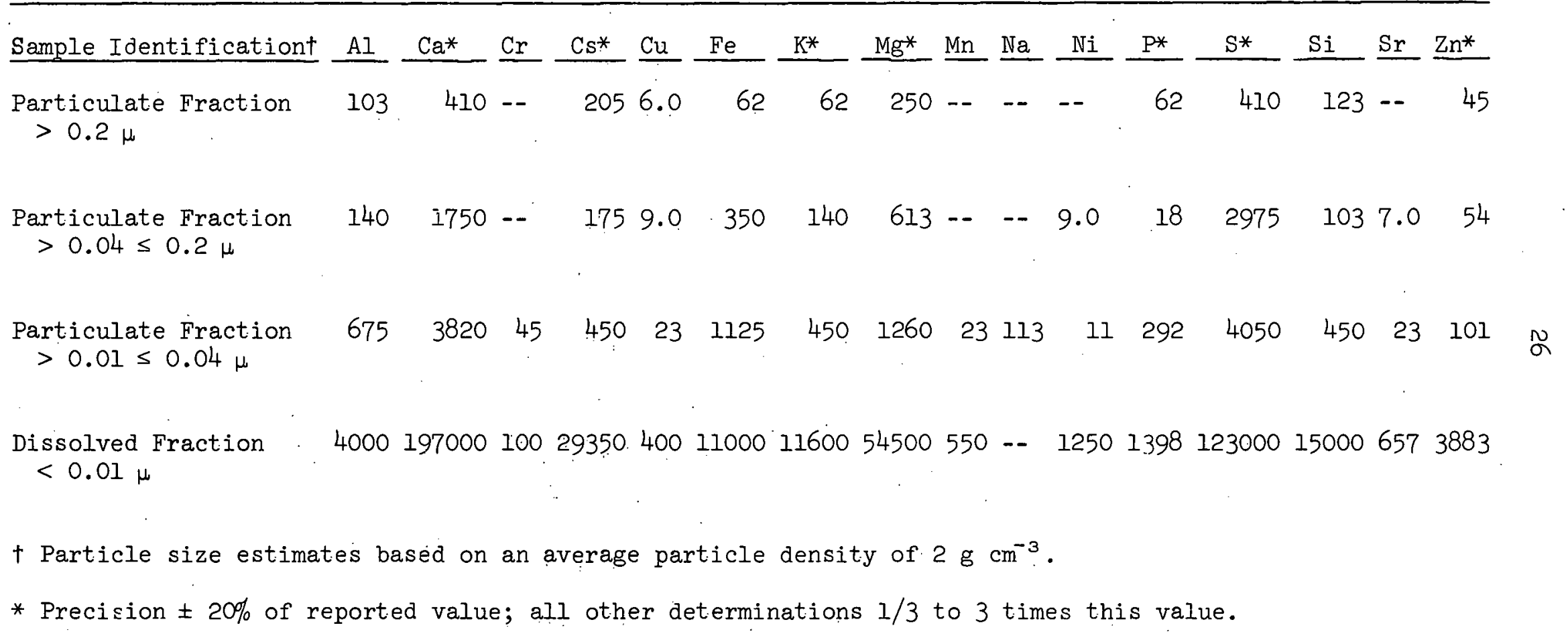


TABLE IX

ELEMENTAL DISTRIBUTION IN REACTOR IOOC INFLUENT WATER (H-2)

(Total Weight in $\mu \mathrm{g}$ )

\begin{tabular}{|c|c|c|c|c|c|c|c|c|c|c|c|c|c|c|c|c|c|}
\hline Sample Identificationt & A I & $\mathrm{Ca}^{*}$ & $\mathrm{Cl} *$ & $\underline{\mathrm{Cr}}$ & $\mathrm{Cu}^{*}$ & $\mathrm{Fe}^{*}$ & $\mathrm{~K}^{*}$ & $\mathrm{Mg*}$ & $\mathrm{Mn}$ & $\mathrm{Na*}$ & $\mathrm{Ni}$ & P* & $S^{*}$ & Si & $\mathrm{Sr}$ & $\mathrm{U}^{*}$ & $\mathrm{Zn} *$ \\
\hline Original Dample & 750 & 361000 & -- & 380 & 190 & 380 & 22800 & 95000 & 152 & 57000 & -- & 1330 & 361000 & 7600 & -- & 190 & 5700 \\
\hline $\begin{array}{l}\text { Particulate Fraction } \\
>0.4 \mu\end{array}$ & $9 ? 0$ & 21 & -- & 11 & 299 & 390 & 45400 & 69 & - & 20800 & 23 & 16400 & 440 & 115 & - & 25 & 276 \\
\hline $\begin{array}{c}\text { Particulate Fraction } \\
>0.2 \leq 0.4 \mu\end{array}$ & 430 & 271 & -- & 10 & 120 & 163 & 38200 & 43 & -- & 17700 & 22 & 1720 & 4500 & 129 & 8 & 2 & 210 \\
\hline $\begin{array}{l}\text { Particulate Fraction } \\
>0.04 \leq 0.2 \mu\end{array}$ & 880 & 11 & - & 28 & 187 & 990 & 18920 & 22 & -- & 9130 & 22 & 6960 & 240 & 44 & -- & 1 & 363 \\
\hline $\begin{array}{l}\text { Particulate Fraction } \\
>0.01 \leq 0.04 \mu\end{array}$ & 800 & 32 & -- & 20 & 240 & 576 & 13120 & 32 & -- & 6288 & 24 & 7320 & 1500 & 120 & -- & 2 & 344 \\
\hline $\begin{array}{l}\text { Dissolved Fraction } \\
\quad<0.01 \mu\end{array}$ & 21700 & 224000 & 30400 & 217 & 39150 & 8350 & 334000 & 58500 & 800 & 183200 & 1050 & 124400 & 212000 & 21200 & 1050 & 112 & 8750 \\
\hline
\end{tabular}


TABLE X

ELEMEITTAL DISTRIBUTION IN REACTOR IOOC EFFLUENT WATER (H-3)

(Total Weight in $\mu \mathrm{g}$ )

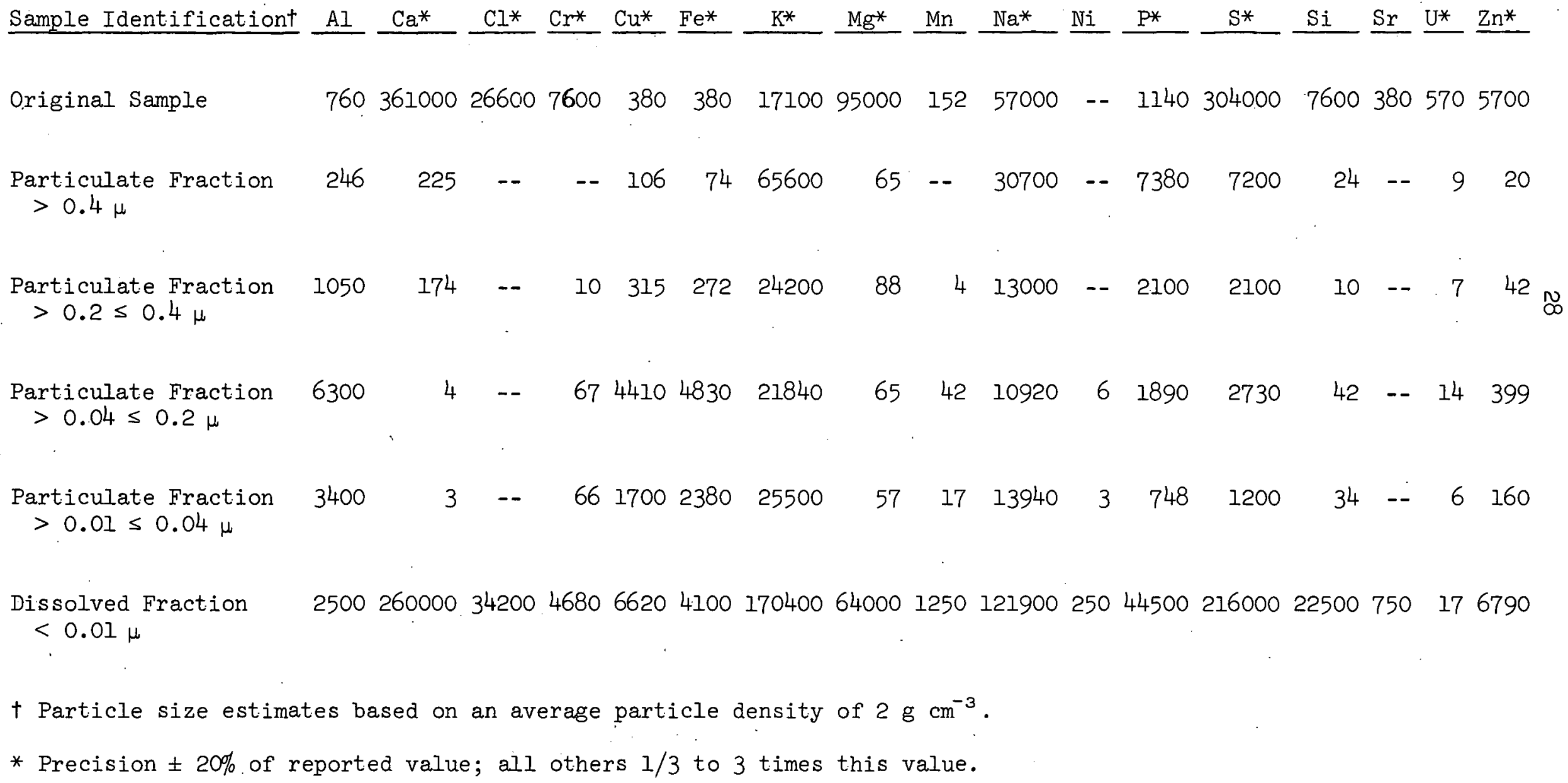


TABLE XI

RADIOACTIVITY DISTRIBUTION IN REACTOR 100C EFFLUENT WATER (H-3)

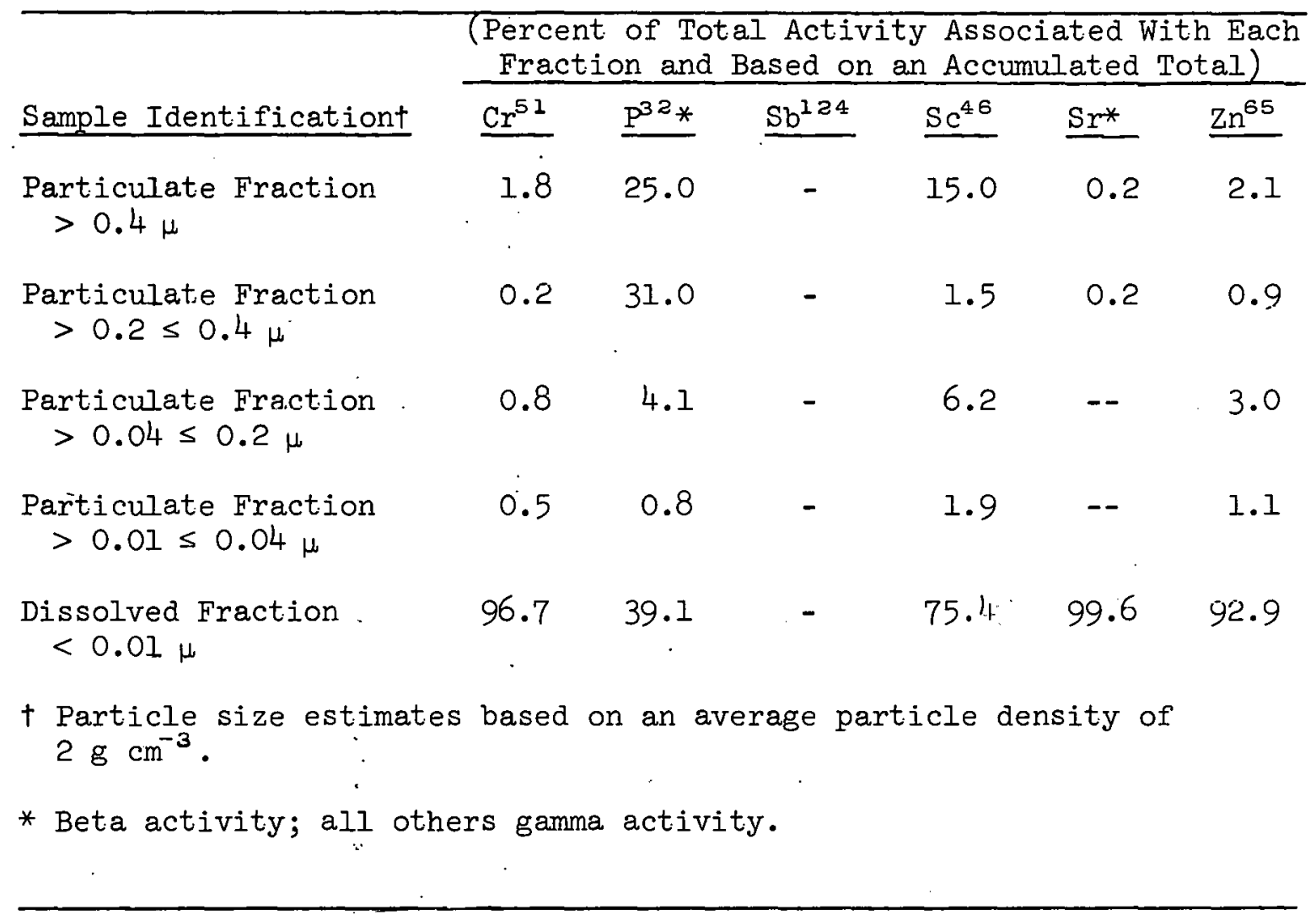


TABLE XII

ELEMENTAL DISTRIBUTION IN COLUMBIA RIVER WATER (H-4)

(Total Weight in $\mu \mathrm{g}$ )

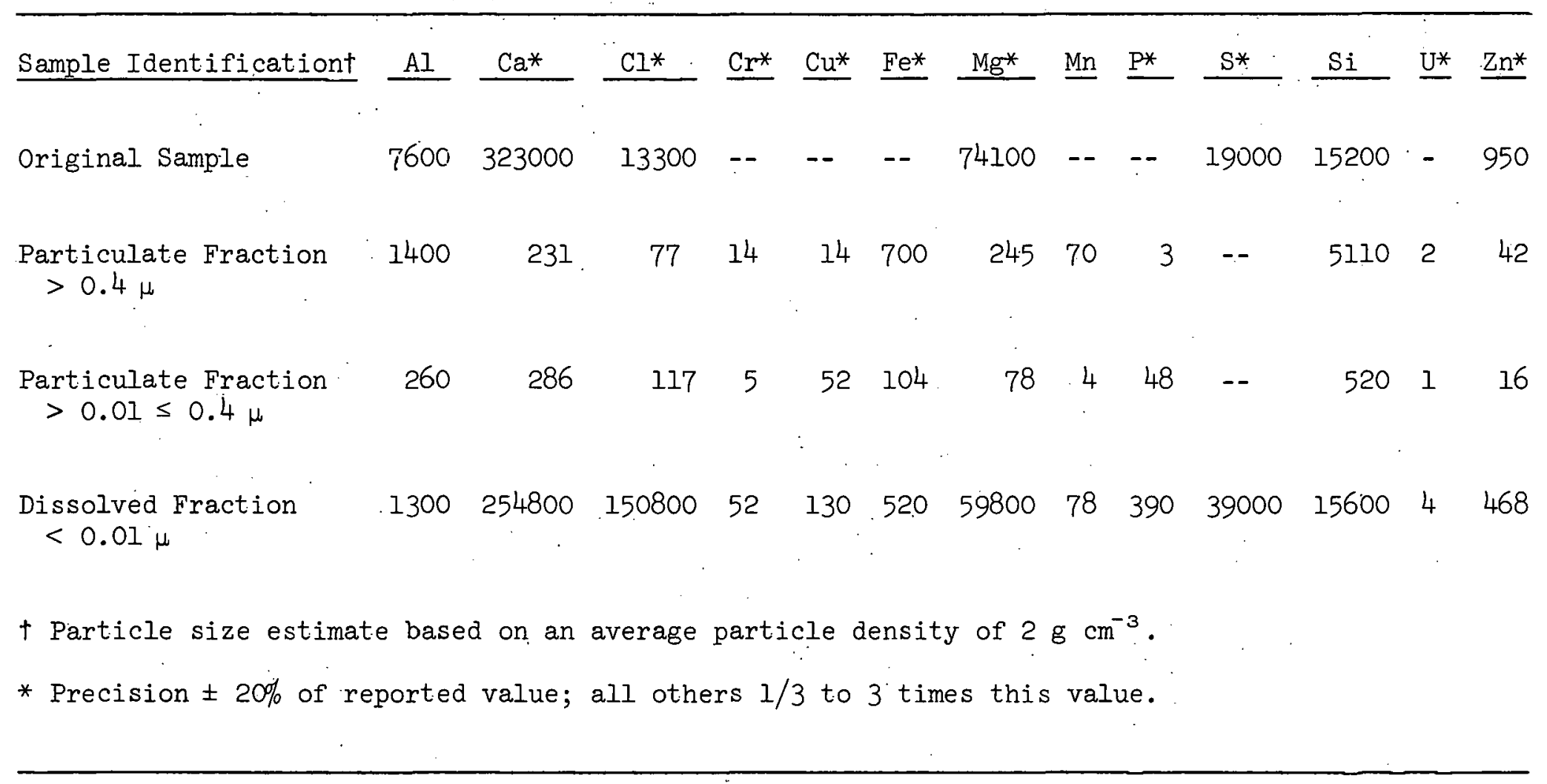


TABLE XIII

ELEMENTAI. DISTRIBUTION IN REACTOR 100K INFLUENT WATER (H-5)

(Total Weight in $\mu \mathrm{g}$ )

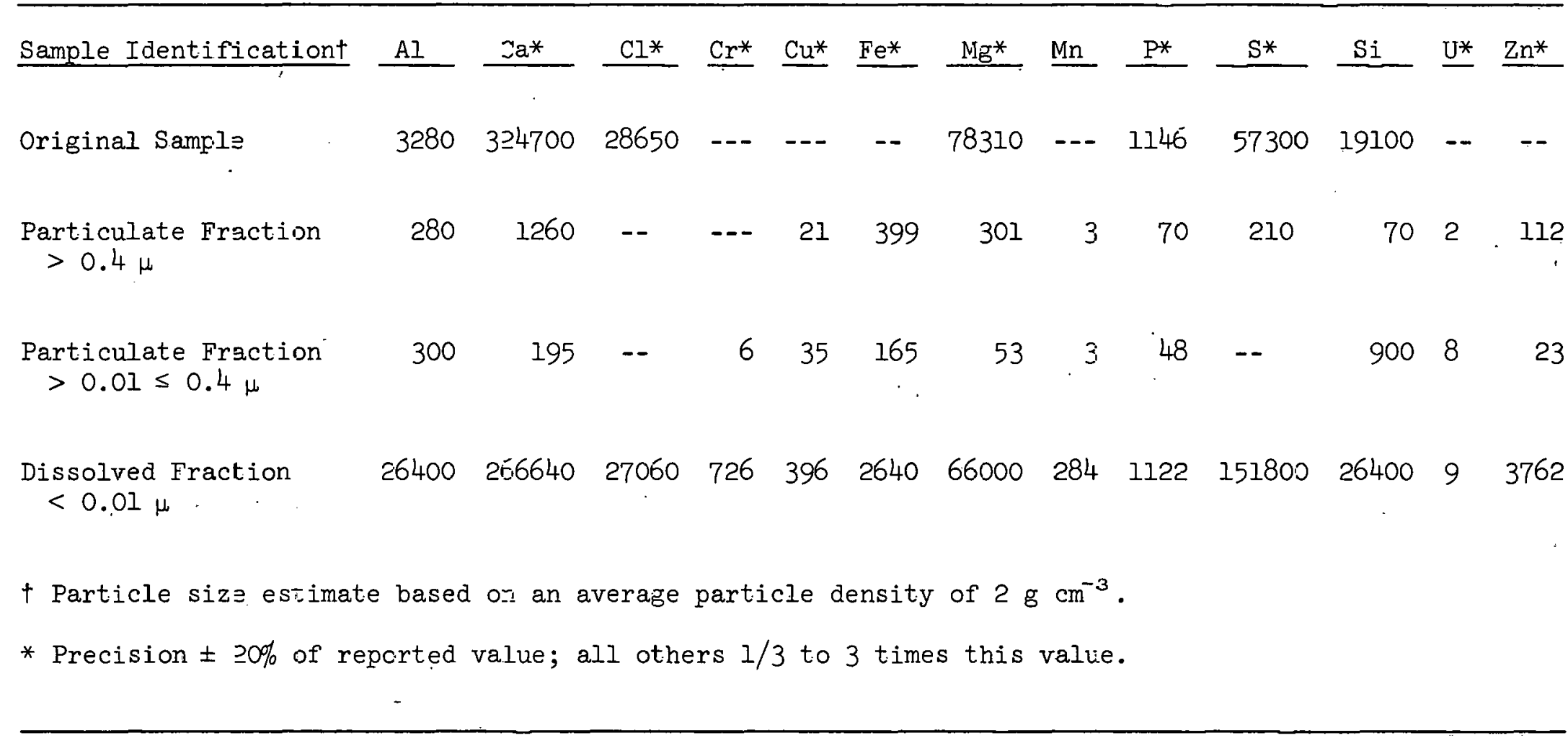


TABLE XIV

ELEMENTAL DISTRIBUTION IN REACTOR 1OOK EFFLUENT WATER (H-6)

(Total Weight in $\mu \mathrm{g}$ )

\begin{tabular}{|c|c|c|c|c|c|c|c|c|c|c|c|c|c|}
\hline Sample Identificationt & $\mathrm{Al}$ & $\mathrm{Ca}^{*}$ & $\mathrm{Cl} *$ & $\underline{\mathrm{Cr}^{*}}$ & $\underline{\mathrm{Cu}}$ & $\underline{\mathrm{Fe}}$ & $\mathrm{Mg*}$ & $\underline{\mathrm{Mn}}$ & $\underline{P^{*}}$ & $S^{*}$ & $\mathrm{Si}$ & $\mathrm{U}^{*}$ & $\underline{\mathrm{Zn}}$ \\
\hline Original Sample ' & 3760 & 300800 & $30 c 80$ & 5640 & 376 & -- & 75200 & -- & 940 & 94000 & 7520 & -- & -- \\
\hline $\begin{array}{l}\text { Particulate Fraction } \\
\quad>0.4 \mu\end{array}$ & 480 & 720 & 80 & 8 & 240 & 120 & 208 & -- & 53 & -- & 160 & 9 & 48 \\
\hline $\begin{array}{l}\text { Particulate Fraction } \\
\quad>0.01 \leq 0.4 \mu\end{array}$ & 440 & 286 & -- & 11 & 72 & 121 & 84 & 4 & 26 & -- & 220 & 7 & 35 \\
\hline $\begin{array}{l}\text { Dissolved Fraction } \\
<0.01 \mu\end{array}$ & 2400 & 168000 & 25500 & 5400 & 120 & 150 & 68100 & 90 & 210 & 99000 & 15000 & 102 & 1230 \\
\hline $\begin{array}{l}\text { † Particle size estima } \\
\text { * Precision } \pm 20 \% \text { of } r\end{array}$ & $\begin{array}{l}\text { te bas } \\
\text { eporte }\end{array}$ & ed on an & $\begin{array}{l}\text { averag } \\
\text { all ot }\end{array}$ & $\begin{array}{l}\text { e part } \\
\text { hers } 1\end{array}$ & $\begin{array}{l}\text { icle } \\
/ 3 \text { to }\end{array}$ & $\begin{array}{l}\text { densi } \\
3 \text { ti }\end{array}$ & $\begin{array}{l}\text { ity of } 2 \\
\text { imes thi }\end{array}$ & $\mathrm{s} \mathrm{v}$ & & & & & \\
\hline
\end{tabular}


TABLE XV

RADIOACTIVITY DISTRIBUTION IN REACTOR IOOK EFFLUENT WATER (H-6) TOTAL ACTIVITY IN PICOCURIES**

\begin{tabular}{|c|c|c|c|c|c|c|}
\hline Sample Identificationt & $\mathrm{Cr}^{51}$ & $\mathrm{P}^{32} *$ & $\underline{\mathrm{Sb}^{124}}$ & $S c^{46}$ & $\mathrm{Sr}^{*}$ & $\mathrm{Zn}^{65}$ \\
\hline Original Sample & $\begin{array}{r}3,620,000 \\
\pm 7 \%\end{array}$ & $\begin{array}{r}121,500 \\
\pm 11 \%\end{array}$ & $\begin{array}{r}53,000 \\
\pm 75 \%\end{array}$ & $\begin{array}{l}67,500 \\
\pm .31 \%\end{array}$ & $\begin{array}{l}8,010 \\
\pm 14 \%\end{array}$ & $\begin{array}{r}89,900 \\
\pm 28 \%\end{array}$ \\
\hline $\begin{array}{l}\text { Particulate Fraction } \\
>0.4 \mu\end{array}$ & $\begin{array}{r}50,700 \\
\pm 1 \%\end{array}$ & $\begin{array}{r}14,700 \\
\quad \pm 5 \%\end{array}$ & -- & $\begin{array}{r}5,740 \\
\pm 2 \%\end{array}$ & $\begin{array}{r}5 \\
\pm 37 \%\end{array}$ & $\begin{array}{r}1,298 \\
\pm 5 \%\end{array}$ \\
\hline $\begin{array}{l}\text { Particulate Fracticn } \\
\quad>0.01 \leq 0.4 \mu\end{array}$ & $\begin{array}{r}3,410 \\
\pm 5 \%\end{array}$ & $\begin{array}{r}2,180 \\
\pm 6 \%\end{array}$ & -- & $\begin{array}{r}404 \\
\pm 5 \%\end{array}$ & $\begin{array}{r}1 \\
\pm 56 \%\end{array}$ & $\begin{array}{r}9 \\
\pm 100 \%\end{array}$ \\
\hline $\begin{array}{l}\text { Dissolved Fraction } \\
\quad<0.01 \mu\end{array}$ & $\begin{array}{r}3,3 L 0,000 \\
\pm 1 \%\end{array}$ & $\begin{array}{l}71,300 \\
\pm 5 \%\end{array}$ & $\begin{array}{r}49,300 \\
\pm 3 \%\end{array}$ & $\begin{array}{r}5,630 \\
\pm 9 \%\end{array}$ & $\begin{array}{r}809 \\
\pm 9 \%\end{array}$ & $\begin{array}{r}11,400 \\
\pm 4 \%\end{array}$ \\
\hline \multicolumn{6}{|c|}{ ** Corrected ta date of sampling. } & \\
\hline
\end{tabular}


TABLE XVI

ELEMENTAL DISTRIBUTION IN REACTOR 100K INFLUENT WATER (H-7)

(Total Weight in $\mu \mathrm{g}$ )

\begin{tabular}{|c|c|c|c|c|c|c|c|c|c|c|c|c|c|}
\hline Sample Identificationt & $\mathrm{Al}$ & $\mathrm{Ca}^{*}$ & $\mathrm{Cl} *$ & $\underline{\mathrm{Cr}} \underline{\underline{H}}^{*}$ & $\underline{\mathrm{Cu}}$ & $\mathrm{Fe}^{*}$ & $\mathrm{Mg*}$ & $\underline{\mathrm{Mn}}$ & $\underline{P^{*}}$ & $S^{*}$ & $\mathrm{Si}$ & $\underline{\mathrm{U}^{*}}$ & $\underline{\mathrm{Zn}}$ \\
\hline Original Sample & 1536 & 652000 & $499 ? 0$ & 384 & 384 & 1920 & 176640 & 115 & 768 & 241920 & 15360 & - & 4224 \\
\hline $\begin{array}{l}\text { Particulate Fraction } \\
\quad>0.01\end{array}$ & 413 & 5395 & 819 & 12 & 52 & 2806 & 1426 & 7 & 109 & 2138 & 663 & 8 & 116 \\
\hline $\begin{array}{l}\text { Dissolved Fraction } \\
\quad<0.01 \mu\end{array}$ & 4000 & 550000 & 115000 & 350 & 300 & 500 & 150000 & 50 & 300 & 305000 & 48000 & 3 & 3400 \\
\hline $\begin{array}{l}+ \text { Particle size estima } \\
\text { * Precision } \pm 20 \% \text { of } r\end{array}$ & $\begin{array}{l}\text { base } \\
\text { orted }\end{array}$ & $\begin{array}{l}\text { on an } \\
\text { value; }\end{array}$ & $\begin{array}{l}\text { average } \\
\text { all othe }\end{array}$ & part & tc & $\begin{array}{l}\text { nsity } \\
\text { time }\end{array}$ & $\begin{array}{l}\text { of } 2 \mathrm{~g} \\
\text { s this } v\end{array}$ & alue. & & - & & & \\
\hline
\end{tabular}


TABLA XVII

ELEMENTAL DISTRIBUTION IN REACTOR 100K EFFLUENT WATER (H-8)

(Total Weight in $\mu g$ )

\begin{tabular}{|c|c|c|c|c|c|c|c|c|c|c|c|c|c|}
\hline Original Sample & 1050 & 630000 & 38500 & 10500 & 700 & 175 & 161000 & 105 & 350 & 220500 & 14400 & 00 & 7000 \\
\hline $\begin{array}{l}\text { Particulate Fraction } \\
\quad>0.01 \mu\end{array}$ & 385 & $E 034$ & 700 & 119 & 53 & 142 & 1582 & 5 & 225 & 2450 & 350 & 196 & 105 \\
\hline $\begin{array}{l}\text { Dissolved Fraction } \\
\quad<0.01 \mu\end{array}$ & 3060 & 510000 & 32300 & 10880 & 680 & 272 & 122400 & 136 & $47 \epsilon$ & 272000 & 40460 & 4 & 2040 \\
\hline
\end{tabular}




\section{TABLE XVIII}

RADIOACTIVITY DISTRIBUTION IN REACTOR 10OK EFFLUENT WATER (H-8) TOTAL ACTIVITY IN PICOCURIES***

\begin{tabular}{|c|c|c|c|c|c|c|}
\hline Sample Identificationt & $\mathrm{Cr}^{51}$ & $\underline{P}^{32} *$ & $\mathrm{Sb}^{124}$ & $\mathrm{Sc}^{46}$ & $\mathrm{Sr}^{*}$ & $\mathrm{Zn}^{65}$ \\
\hline Original Sample & $\begin{array}{r}8,400,000 \\
\pm 6 \%\end{array}$ & $\begin{array}{l}261,000 \\
\quad \pm 11 \%\end{array}$ & $\begin{array}{r}116,200 \\
\pm 64 \%\end{array}$ & $\begin{array}{r}146,800 \\
\quad \pm 27 \%\end{array}$ & $\begin{array}{l}1320 \\
\pm 100 \%\end{array}$ & $\begin{array}{r}179,000 \\
\pm 27 \%\end{array}$ \\
\hline $\begin{array}{l}\text { Particulate Fraction } \\
\quad>0.01 \mu\end{array}$ & $\begin{array}{r}115,500 \\
\pm 8 \%\end{array}$ & $\begin{array}{l}75,200 \\
\pm 5 \%\end{array}$ & $\begin{array}{l}15,900 \\
\pm 50 \%\end{array}$ & $\begin{array}{l}18,010 \\
\pm 5 \%\end{array}$ & $\begin{array}{ll} & 21 \\
\pm & 100 \%\end{array}$ & $\begin{array}{l}2,100 \\
\pm 24 \%\end{array}$ \\
\hline $\begin{array}{l}\text { Dissolved Fraction } \\
\quad<0.01 \mu\end{array}$ & $\begin{array}{r}7,650,000 \\
\pm 3 \%\end{array}$ & $\begin{array}{r}178,000 \\
\pm 4 \%\end{array}$ & $\begin{array}{r}39,000 \\
\pm 11 \%\end{array}$ & $\begin{array}{r}100,000 \\
\pm 4 \%\end{array}$ & $\begin{array}{c}5 \\
\pm 100 \%\end{array}$ & $\begin{array}{r}156,000 \\
\pm 4 \%\end{array}$ \\
\hline \multicolumn{7}{|c|}{ + Particle size estimate based on an average particle density of $2 \mathrm{~g} \mathrm{~cm}^{-3}$} \\
\hline $\begin{array}{l}\text { * Corrected to date of } \\
\text { * Beta activity; all o }\end{array}$ & $\begin{array}{l}\text { ing. } \\
\text { gamma acti }\end{array}$ & & & & & \\
\hline
\end{tabular}

